\author{
J. Klett*, T. Hassel \\ Leibniz Universität Hannover, Institut für Werkstoffkunde (Materials Science), An der \\ Universität 2, 30823 Garbsen, Germany \\ *klett@iw.uni-hannover.de
}

\title{
INFLUENCE OF STICK ELECTRODE COATING'S MOISTURE CONTENT ON THE DIFFUSIBLE HYDROGEN IN UNDERWATER WET SHIELDED METAL ARC WELDING
}

\begin{abstract}
In shielded metal arc welding, the major factors influencing hydrogen uptake into the weld metal are (i) the hydrogen content of the base metal, (ii) hydrogen input by the welding consumable, and (iii) the hydrogen introduced by the atmosphere surrounding the arc process. In this study, the relative contribution of these factors is investigated and compared to each other for the case of underwater wet shielded metal arc welding. To assess the influence of the stick electrode's moisture (capillary introduced water during handling operations) on the diffusible hydrogen in wet welded samples, wet and dry electrodes were welded at four different water depths. The moisture was absorbed through the sharpened electrode tip only, to ensure close to service conditions. The results show that the moist stick electrode coatings lead to $22.6 \%$ higher average diffusible hydrogen content in the weld metal ( $0.5 \mathrm{~m}$ water depth an average). However, the effect disappears with increasing water depths (no difference in $60 \mathrm{~m}$ water depth).
\end{abstract}

Keywords: Underwater wet welding; SMAW; diffusible hydrogen; water depth; electrode coating moisture

\section{INTRODUCTION}

Hydrogen induced cracking is one of the major challenges in underwater wet welding of steel [1-3]. This is due to the high diffusible hydrogen content, combined with high hardness and stress in the heat affected zone (HAZ) of wet welds [4, 5]. Recent research aimed at resolving this challenge by either lowering the diffusible hydrogen content, or the hardness of the HAZ. Positive results were achieved by altering the stick electrodes' coating [6, 7], and by adjusting the chemical composition of the welding consumables' core wire [8-11]. A reduction of the hardness of the HAZ was achieved by applying the temper bead welding method [5, 12-15], and by adding an induction heat treatment process [16-18]. Both methods also show potential to reduce the diffusible hydrogen content simultaneously, if the post heat treatment process leads to hydrogen soaking (i.e. accelerated diffusion of hydrogen out of the weldment due to raised temperature). Other studies focus solely on flux cored arc welding (FCAW) and though they show high potential, these results are not directly applicable to SMAW [19-21, 37]. 
Besides the invention of new methods to reduce the diffusible hydrogen content and / or the hardness in the HAZ, understanding the origin of the diffusible hydrogen is important. The latter, can lead to new approaches that help curtailing the hydrogen uptake from these sources.

In 1992, Li and North differentiated between the key influencing factors to be considered when the diffusible hydrogen content of weldments is discussed [22]. These can be summarized as follows:

- moisture in flux and coating for shielded metal arc welding, flux cored arc welding, and submerged arc welding,

- moisture or purposely added hydrogen in the shielding gas for gas metal arc welding (GMAW), and gas tungsten arc welding,

- hydrogenous compounds on the base metal surface (e.g. oil, sealing, and coating),

- hydrogen content of the base metal or the welding wire, and

- the humidity of the surrounding atmosphere.

Regarding the SMAW-process, the welding consumable's hydrogen content includes the hydrogen content of the core wire as well as of the surrounding coating. For underwater wet welding, it seems obvious that the replacement of air by water as the surrounding atmosphere will have a huge impact on the diffusible hydrogen uptake. By comparison, the base metals surface conditions (e.g. residual oil) might not be that influential. Besides, this hydrogen source can easily be removed by appropriate cleaning processes.

For atmospheric dry welding, Kiefer found that moisture in the shielding gas of GMAW leads to higher diffusible hydrogen contents (approximately 5 to $8 \mathrm{ml} / 100 \mathrm{~g}$ more compared to dry gas) $[23,24]$. The total hydrogen content in the welding wire was found to increase the diffusible hydrogen content, too (up to $11 \mathrm{ml} / 100 \mathrm{~g}$ higher diffusible hydrogen content) [23]. However, this value is rather hard to control. It was also stated that the humidity of the surrounding air could have an even bigger influence on the diffusible hydrogen content [23]. In underwater wet welding, this clearly is the case. The diffusible hydrogen contents found here by far exceed the values reported by Kiefer. They usually vary from $21 \mathrm{ml} / 100 \mathrm{~g}$ in the case of underwater wet FCAW [2] to over $100 \mathrm{ml} / 100 \mathrm{~g}$ for wet SMAW [25].

For SMAW, the moisture of the electrodes' coating is an important issue. The German DVS note no. 1818, an instruction on the "Execution of arc welding work in wet environment", which is used as the standard for the training of welding divers, states: "Stick electrodes that have been in water for a longer period of time must not be used because their coating may have absorbed water." [26]. In 2019 it was shown that absorbed moisture, due to the storage conditions (expose to humid air) of stick electrodes, leads to increased diffusible hydrogen contents $[27,28]$. The difference was significant $(\mathrm{p}<0.05$; mean differences: 1.7 $\mathrm{ml} / 100 \mathrm{~g}$ when welded dry, $3 \mathrm{ml} / 100 \mathrm{~g}$ when welded wet). This made up for about $5 \%$ increase, while the difference between wet and dry welding was $23 \mathrm{ml} / 100 \mathrm{~g}$ ( $65 \%$ increase).

In 2015, Kussike investigated the moisture absorption of stick electrodes depending on the water depth they were exposed to [25]. He examined five conventional stick electrodes for wet welding and additionally investigated the influence of three different waterproof coatings, which surround the electrodes, on their effect on moisture absorption. He compared these values with the moisture absorption of hydrophobic electrodes. For this he used 15 different hydrophobising agents and applied them to the electrodes coating. He found out, that a raising water depth (higher pressure) leads to increased water absorption in all cases. He also found that traditional resin based coatings lead to less water absorption than hydrophobic coatings, if 
the electrodes coating is treated before pressing the electrodes. If the electrode (without waterproof coating) is dunked into a liquid hydrophobing agent, the moisture absorption can be reduced but never falls below the values reached by an alkyd resin based sealing surrounding the whole coating [25]. However, this does not necessarily mean that the lowest moisture also leads to the lowest diffusible hydrogen contents. Hydrogen contained within the waterproof coating should be considered, too. In 2020, Tomków, Fydrych and Wilk stated that paraffin wax used as a waterproof coating led to the lowest diffusible hydrogen content in a test of six different coating types [29].

The objective of the present study was the evaluation of the relative effect of the stick electrodes' moisture on the diffusible hydrogen content in wet welded samples, compared to the influence of the surrounding water, and the water depth.

\section{METHODS AND MATERIALS}

To estimate the influence of the stick electrodes' moisture on the diffusible hydrogen in wet welded samples, artificially wetted and dry standard electrodes were welded at four different water depths.

Underwater wet SMAW was performed in a hyperbaric welding chamber. The chamber, with an inner volume of $10 \mathrm{~m}^{3}$, contains a custom-made multi-axis welding machine with an arc voltage controlled axis enabling a constant arc length throughout the welding process. Up to 100 stick electrodes can be stored in a dry magazine and can be exchanged automatically by the manipulator. The chamber was filled with fresh water and pressurised using a pneumatic system to simulate different water depth $[4,25,30]$. For the analysis of diffusible hydrogen contents in wet weldments, a manipulator system was installed within the chamber (Fig. 1). The system allows the weldment of up to 15 samples following the industrial standard (ISO 3690 - sample geometry C [31], Fig. 2) without opening the chamber. After welding, the samples were directly stored in liquid nitrogen, following the instructions given in ISO 3690 adjusted for wet welding [31, 32].

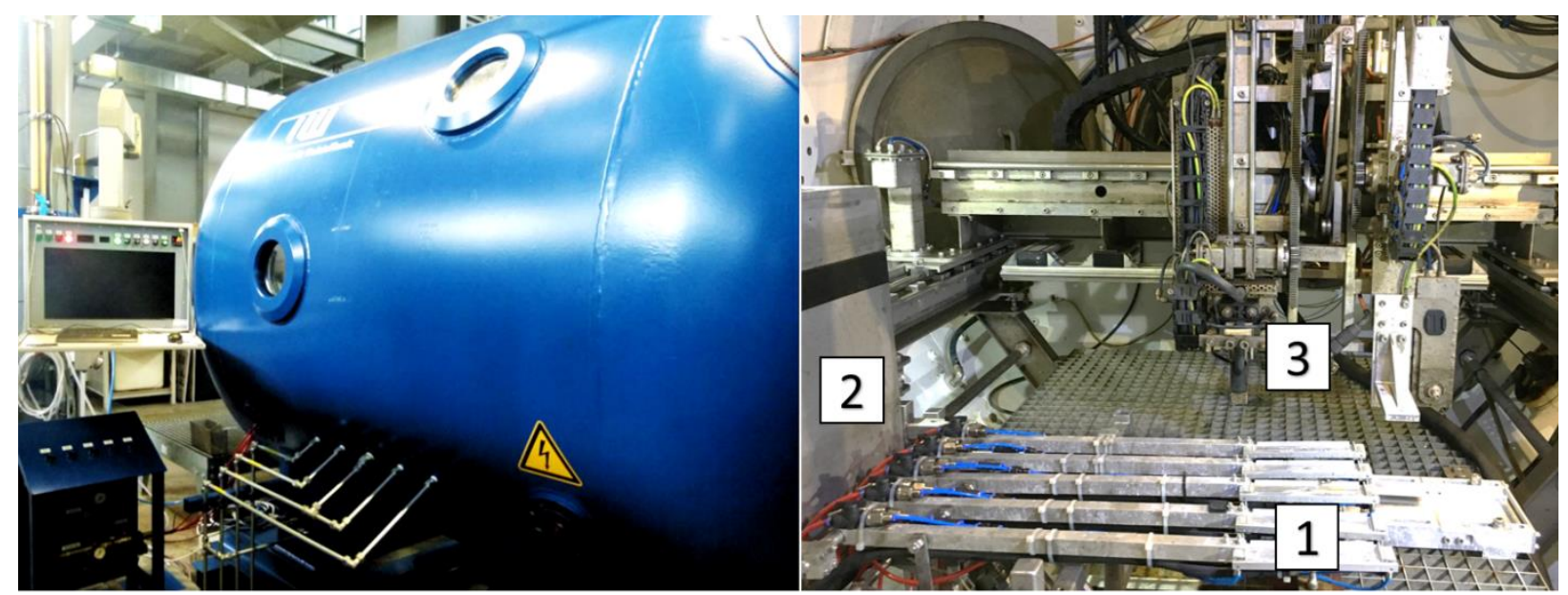

Fig. 1. left: $10 \mathrm{~m}^{3}$ welding chamber used for hyperbaric wet welding; right: system for the weldment of hydrogen samples based on ISO 3690: 1) Clamping system for five samples according to ISO 3690 - sample geometry C

(s. Fig. 2); 2) Insulated tank containing $0.02 \mathrm{~m}^{3}$ of liquid nitrogen; 3) Welding axis with the electrode holder 


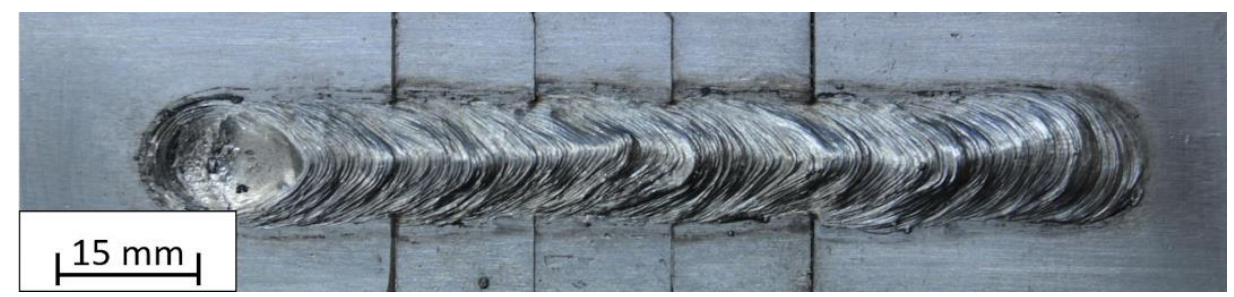

Fig. 2. Sample welded automatically in the pressure chamber (Fig 1) in accordance to ISO 3690 - sample geometry $\mathrm{C}$

For all tests, a rutile based experimental stick electrode with $\varnothing 3.25 \mathrm{~mm}$ ferritic core wire $(0.05 \% \mathrm{C}, 0.25 \% \mathrm{Si}, 0.5 \% \mathrm{Mn}, 0.5 \% \mathrm{Mo})$ was used. The core wire is surrounded by a coating and an additional waterproof alkyd resin based sealing adding up to $\varnothing 5.5 \mathrm{~mm}$ outer diameter. The chemical composition of the electrodes' coating is given in table 1. All electrodes were welded using negative (DCEN) polarity. The welding parameters for each individual water depth are given in table 2 . The base material was S235 JR structural steel $(0.15 \% \mathrm{C}, 0.81 \%$ $\mathrm{Mn}, 0.03 \% \mathrm{Cr}, 0.02 \% \mathrm{Mo}, 0.02 \% \mathrm{Ni}, 0.02 \% \mathrm{Cu}, 0.01 \% \mathrm{~V}$; $\left.\mathrm{CE}_{\text {IIW }}=0.3 \%\right)$.

Table 1. Composition of the electrode's coating (in wt.-\%)

\begin{tabular}{cc}
\hline coating ingredient & Proportion in wt.-\% \\
$\mathrm{CaCO}_{3}$ & 20 \\
$\mathrm{FeMn}$ & 12 \\
$\mathrm{Fe}$ & 1 \\
$\mathrm{TiO}_{2}$ & 51 \\
$\mathrm{Al}_{4}(\mathrm{OH})_{8}\left[\mathrm{Si}_{4} \mathrm{O}_{10}\right]$ & 2 \\
$\mathrm{C}_{6} \mathrm{H}_{10} \mathrm{O}_{5}$ & 2 \\
$\mathrm{SiO}_{2}$ & 12 \\
total & 100
\end{tabular}

Table 2. Welding parameters: Arc voltage and welding current are mean values measured during the welding of the samples (measurement time: $10 \mathrm{~s}$, sampling rate: $10 \mathrm{kHz}$ )

\begin{tabular}{cccc}
\hline $\begin{array}{c}\text { Water depth } \\
(\mathrm{m})\end{array}$ & $\begin{array}{c}\text { Welding } \\
\text { current }(\mathrm{A})\end{array}$ & $\begin{array}{c}\text { Arc } \\
\text { voltage }(\mathrm{V})\end{array}$ & $\begin{array}{c}\text { Welding speed } \\
(\mathrm{m} / \mathrm{min})\end{array}$ \\
\hline 0.5 & 175 & 30 & 0.18 \\
20 & 200 & 26 & 0.18 \\
40 & 200 & 25 & 0.18 \\
60 & 200 & 25 & 0.18 \\
\hline
\end{tabular}

Before welding, the tip of the stick electrodes needs to be sharpened, in order to remove the coating and free the core wire (Fig. 3). This step is the industry standard to realize proper ignition of the arc. 


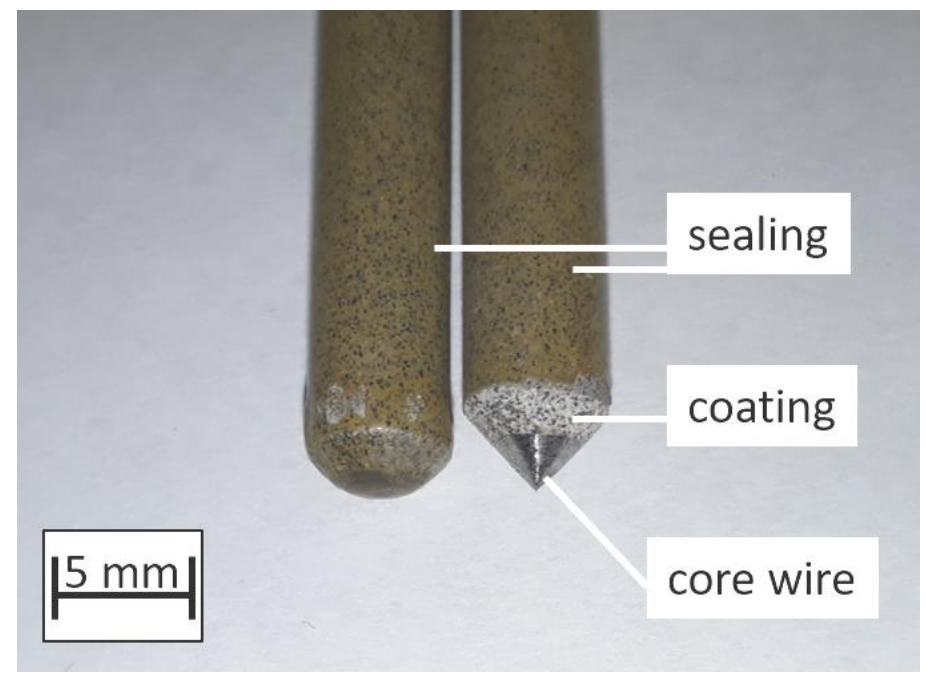

Fig. 3. Left: uncut electrode, the waterproof sealing covers the core wire; right: cut electrode, the area of coating without protective sealing is visible

This part of the stick electrode is the only area, where the inner coating comes into contact with water (without the protection of the waterproof sealing). To estimate the amount of moisture / water absorbed via this area by capillary forces, the stick electrodes were weighed and submerged under water for $24 \mathrm{~h}$ or $48 \mathrm{~h}$. Thereafter, the surfaces were dried and cleaned using air flow. The electrodes were weighed again to determine the mass of absorbed water. The weight difference of each individual stick electrode was noted. The electrodes were then put into the electrode storage of the pressure chamber and welded within $1 \mathrm{~h}$ after weighing. Additional samples with dry electrodes were welded for reference. The same welding parameters were used for dry and wet electrodes.

Sample preparation, welding, and analysis strictly followed the instructions of ISO 3690 modified for wet welding, as explained by Klett et al. [4, 32]. The analysis was performed using the carrier gas hot extraction method at $400{ }^{\circ} \mathrm{C}$ for $1800 \mathrm{~s}$. The analyser was a Bruker G4 Phoenix. For each water depth at least ten samples welded with wet electrodes $(24 \mathrm{~h}$ submerged) were analysed. Ten electrodes were submerged in water for $48 \mathrm{~h}$. These were welded in $0.5 \mathrm{~m}$ water depth. In total, 175 samples were analysed.

\section{RESULTS AND DISCUSSION}

\section{Electrode's moisture and water depth}

The first experiment targeted the influence of the electrodes' moisture on the diffusible hydrogen content in different water depths. Stick electrodes submerged in water for more than $24 \mathrm{~h}$ were excluded from these results. Fig. 4 shows a boxplot of the measured diffusible hydrogen contents at the different water depths.

The diffusible hydrogen contents of each individual group (each depth, dry /wet) were tested for normal distribution, using the Shapiro-Wilk test. Normal distribution can be assumed for all groups $(p>0.05)$. 


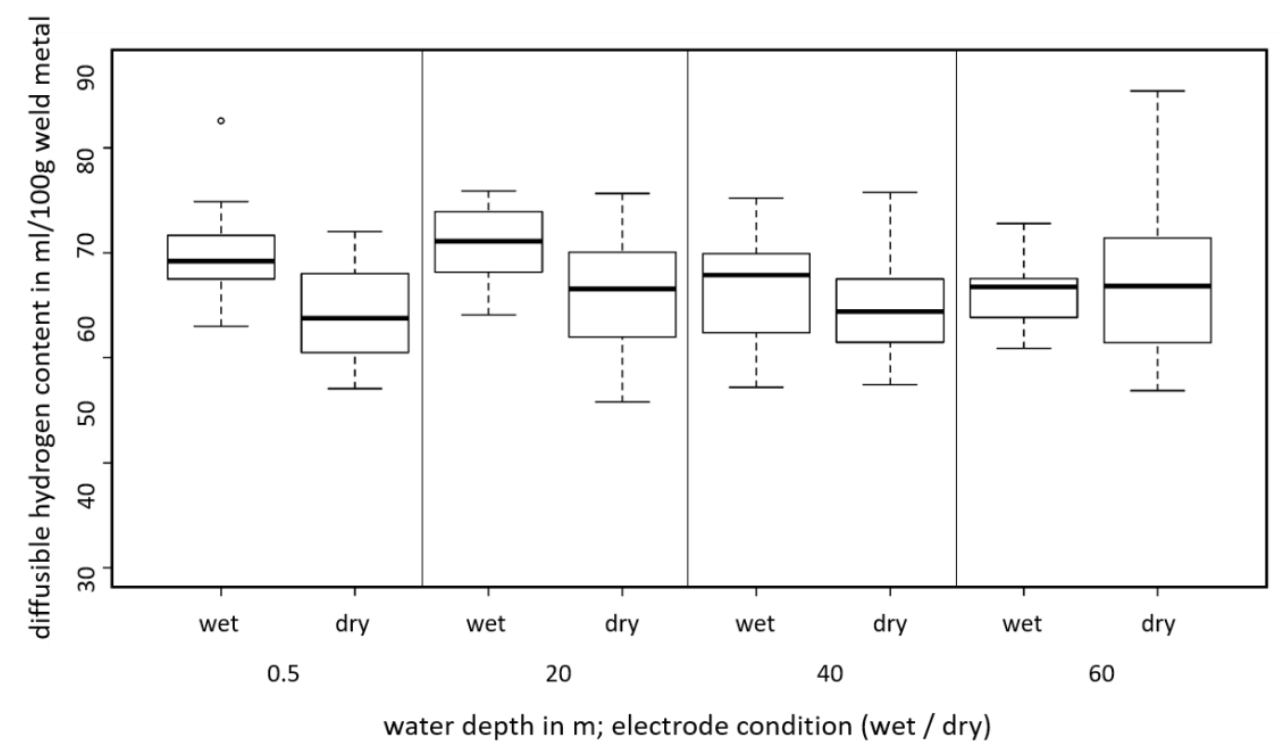

Fig. 4. Influence of the stick electrodes' moisture on the diffusible hydrogen content at different water depth. Displayed as a Boxplot: the horizontal line within the boxes represents the median, the boxes represent the interquartile range. The whiskers show the maximum or minimum of each distribution; outliners are marked with an "o"

The first thing attracting attention in this boxplot is the fact that the water depth does not have a substantial influence on the diffusible hydrogen content. Only for wet stick electrodes a slight decrease in diffusible hydrogen content can be seen. This was further inspected using a multivariate linear regression model including water depth, arc voltage, welding current, and the mass of deposited weld metal (compare [32]) of every sample as the influencing variables and the diffusible hydrogen content as the outcome. For wet electrodes this model explains $63 \%$ of the variance (adj. $R^{2}=0.63$ ), with only the mass and the depth being significant influencing variables. For the dry electrodes, the influence of water depth is not significant. A decrease in the diffusible hydrogen content with increasing water depth was found as well in three prior studies [4, 33, 34], while one also found no influence of the water depth for one stick electrode [4].

For $0.5 \mathrm{~m}, 20 \mathrm{~m}$, and $40 \mathrm{~m}$ water depth an increased diffusible hydrogen content in samples welded with wet stick electrodes could be interpreted from the boxplot. For clarification, a t-test was used individually for each water depth to test for differences between the results of samples welded with wet and dry stick electrodes. For $0.5 \mathrm{~m}$ and $20 \mathrm{~m}$ water depth the difference of the diffusible hydrogen content in samples welded with wet and dry electrodes is significant $(p<0.05)$. For $40 \mathrm{~m}$ and $60 \mathrm{~m}$ the difference is not significant $(p>$ $0.05)$. The mean difference between samples welded with dry and wet stick electrodes is 10.9 $\mathrm{ml} / 100 \mathrm{~g}$ for $0.5 \mathrm{~m}$ and $8.8 \mathrm{ml} / 100 \mathrm{~g}$ for $20 \mathrm{~m}$ water depth. At $0.5 \mathrm{~m}$ water depth, this corresponds to an increase of the diffusible hydrogen content by $22.6 \%$. At $20 \mathrm{~m}$ water depth, $16.8 \%$ more diffusible hydrogen was measured when a wet stick electrode was used. At $40 \mathrm{~m}$ water depth, the difference in means comes down to $4.0 \mathrm{ml} / 100 \mathrm{~g}(8 \%)$ and due to the variance this difference is not significant anymore.

It can be concluded that increasing the water depth leads to less difference in diffusible hydrogen content between samples welded with dry and wet stick electrodes. The influence of the electrodes moisture on the diffusible hydrogen content thus decreases with increasing water depth (Fig 5). 


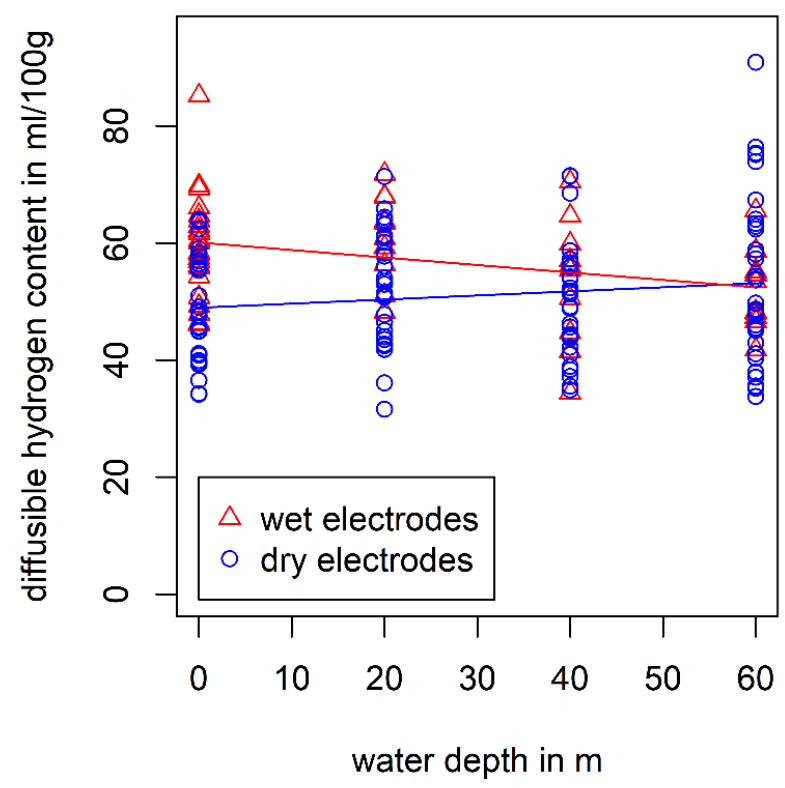

Fig. 5. Correlation of the stick electrodes' moisture and the diffusible hydrogen content at different water depth. Blue: dry electrodes; red: wet electrodes

A multivariate linear regression model was employed using the weight difference before and after submerging in water (i.e. the mass of the absorbed water) of every individual stick electrode, the water depth, the arc voltage, the welding current and the mass of deposited weld metal of every sample as influencing variables and the diffusible hydrogen content as the outcome. This model explains $55 \%$ of the variance (adj. $R^{2}=0.55$ ), but only the absorbed water and the mass of deposited weld metal show significant influence $(p<0.05)$. Reducing the variables to only significant ones leads to an adjusted $R^{2}$ of 0.54 .

The conclusion with respect to practical application is that electrodes that already had their tip cut (waterproof sealing removed, Fig. 3), should be stored dry, because even the small area of uncovered coating around the tip is enough to absorb water, which leads to an increased diffusible hydrogen content. If the waterproof sealing is intact, the storage in water, even for up to six hours and at a water depth of up to $60 \mathrm{~m}$ leads to less than $0.5 \%$ relative moisture absorption if an alkyd resin based sealing with a thickness of $0.09 \mathrm{~mm}$ is used [25]. The relative moisture absorption can be reduced to $0.05 \%$ if a sealing with a thickness of at least $0.16 \mathrm{~mm}$ is used and the tip is completely covered [25]. Two of the five commercially available electrodes tested by Kussike (Hydroweld FS by Hydroweld (UK) and Phoenix Nautica 20 by voestalpine Böhler welding (De)) absorbed less than $0.3 \%$ relative moisture [25].

\section{Electrode's moisture absorption period}

The second welding test aimed at evaluating the effect of moisture absorption periods longer than $24 \mathrm{~h}$. The result of the gravimetric examination shows that a longer submerging period leads to more absorbed moisture. The results of the water absorption test demonstrated a mean difference of $0.24 \mathrm{~g}$ of moisture absorbed by the stick electrodes coating after $24 \mathrm{~h}$. After $48 \mathrm{~h}$ the mean weight difference of the electrodes before and after submerging was $0.51 \mathrm{~g}$.

Samples for hydrogen analyses with the stick electrodes submerged for $48 \mathrm{~h}$ were only welded at $0.5 \mathrm{~m}$ water depth, since the influence of the electrodes moisture was bigger here than for the other water depths. The difference in the diffusible hydrogen content between 
stick electrodes submerged in water for $24 \mathrm{~h}$ or $48 \mathrm{~h}$ was tested using a t-test. No significant difference was found. For closer examination of the results a plot showing the diffusible hydrogen content correlated to the individual weight difference (i.e. mass of absorbed water) of the stick electrodes the samples were welded with is shown in Fig. 6. Besides showing a rather large variance in the diffusible hydrogen content, it can be assumed that an influence of the mass of absorbed water on the diffusible hydrogen content is only found below $0.3 \mathrm{~g}$ of absorbed water. Though this may look like a saturation process, another explanation can be found if the water absorption is closer looked upon: The water is absorbed only in the area of the stick electrode's sharpened tip (Fig. 3). The fact that more water is absorbed after $48 \mathrm{~h}$ than after $24 \mathrm{~h}$ shows that the hygroscopic properties of the electrode's coating transports water from the tip further up the electrode by capillary forces. This means that the part of the electrode that is used for welding the hydrogen samples, is saturated with water after $24 \mathrm{~h}$. After $48 \mathrm{~h}$, more water is absorbed, but the part of the electrode were this water is transported to, is not involved in the welding anymore. It can be assumed that less than $0.3 \mathrm{~g}$ of water is sufficient to saturate the first $100 \mathrm{~mm}$ of the stick electrode, which is enough to weld samples in accordance to ISO 3690 - sample geometry C.

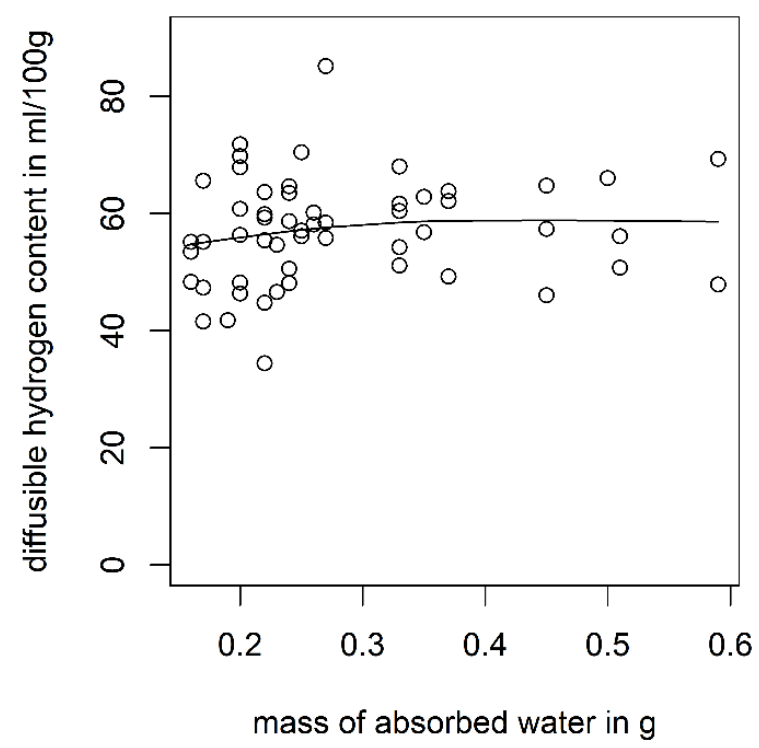

Fig. 6. Correlation between diffusible hydrogen and mass of water absorbed by the stick electrode, prior to welding

The highest mean difference in diffusible hydrogen measured in this study was the difference between wet and dry stick electrodes welded at $0.5 \mathrm{~m}$ water depth. This difference was $10.9 \mathrm{ml} / 100 \mathrm{~g}$. This makes up for $18.4 \%$ of the mean diffusible content of all samples welded with a wet stick electrode at $0.5 \mathrm{~m}$ water depth $(59.3 \mathrm{ml} / 100 \mathrm{~g})$. Assuming that quality welds produced by dry SMAW of rutile based stick electrodes in air atmosphere are expected to reach less than $35 \mathrm{ml} / 100 \mathrm{~g}[27,35]$, the effect of the surrounding water makes up for almost $28 \%$ of the diffusible hydrogen content in underwater wet SMAW with dry stick electrodes. This means that more than $50 \%$ of the weld metal's hydrogen content could be caused by the stick electrode's coating (chemical composition), the core wire, and the base material. Less than $30 \%$ are caused by the surrounding atmosphere and the stick electrode's moisture is responsible for the remaining $20 \%$ or less. However, this might only be valid for the materials presented in this study. In the 2019 study by Tomków et al. the mean diffusible hydrogen content of dry welded rutile based stick electrodes reached $60.9 \%$ of the mean diffusible hydrogen content generated by wet welding with the same electrodes [27]. In this case the change from air atmosphere to water made up for almost $40 \%$ of the diffusible 
hydrogen in the weld metal. The welding polarity could also affect the hydrogen intake caused by the coating's moisture, since it was shown to influence the heat distribution in the arc column [36].

The present study is a first step to quantify the relative contributions of different factors influencing the diffusible hydrogen intake into the weld metal. Clearly, a better understanding of the processes in the gas/steam bubble surrounding the arc is needed to further improve underwater wet welding. In addition, the composition of the arc atmosphere needs to be evaluated in detail. In order to be able to quantify in the correlations between electrode-based hydrogen input and environmental input into the welding area by the water, the hydrogen content in the arc must be quantifiably assigned to the respective causes.

\section{CONCLUSIONS}

The present study investigated the influence of the stick electrode's moisture on the diffusible hydrogen content in the weld metal. The main findings can be summarized as follows:

1) Wet electrodes lead to higher diffusible hydrogen contents.

2) The influence of the electrode's moisture on the diffusible hydrogen content in the deposited weld metal is smaller than the influence of the surrounding water.

3) Increasing water depth decreased the influence of the electrode's moisture on the diffusible hydrogen content in the deposited weld metal.

4) For wet stick electrodes, increasing water depth led to lower diffusible hydrogen contents in the deposited weld metal.

With respect to application, it is important to note that underwater wet welding operations at shallow depths react much more sensitively to the moisture of stick electrodes than at depths greater than $20 \mathrm{~m}$. Thus, the quality of the underwater welding work can be significantly improved if the diver sharpens the electrode shortly before the start of the welding process, as this allows reducing the amount of hydrogen entering the weld metal.

\section{ACKNOWLEDGEMENTS}

The authors thank Kjellberg Finsterwalde for producing and providing the experimental stick electrodes used in this study.

\section{REFERENCES}

1. Fydrych, D., Labanowski, J., Tomków, J., Rogalski, G. (2015). Cold cracking of underwater wet welded S355G10+N high strength steel. Adv. Mater. Sci. 15 (3), 48-56. https://doi.org/10.1515/adms-2015-0015

2. Świerczyńska, A., Fydrych, D., Rogalski, G. (2017). Diffusible hydrogen management in underwater wet self-shielded flux cored arc welding. Int. J. Hydrogen Energy 42 (38), 2453224540. https://doi.org/10.1016/j.ijhydene.2017.07.225

3. Tomków, J., Łabanowski, J., Fydrych, D., Rogalski, G. (2018). Cold cracking of S460N steel in water environment. Pol. Marit. Res. 25 (3), 131-136. https://doi.org/10.2478/pomr-2018-0104 
4. Klett, J., Hecht-Linowitzki, V., Grünzel, O., Schmidt, E., Maier, H.J., Hassel, T. (2020). Effect of the water depth on the hydrogen content in SMAW wet welded joints. SN Appl. Sci. 2, 1269. https://doi.org/10.1007/s42452-020-3066-8

5. Tomków, J., Rogalski, G., Fydrych, D., Łabanowski, J. (2018). Improvement of S355G10+N steel weldability in water environment by Temper Bead Welding. J. Mater. Process. Technol., 262, 372-381. https://doi.org/10.1016/j.jmatprotec.2018.06.034

6. Menezes, P.H.R., Pessoa, E.C.P., Bracarense, A.Q. (2019). Comparison of underwater wet welding performed with silicate and polymer agglomerated electrodes. J. Mater. Process. Technol., 266, 63-72. https://doi.org/10.1016/j.jmatprotec.2018.10.019

7. Santos, V.R., Monteiro, M.J., Rizzo, F.C., Bracarense, A.Q., Pessoa, E.C.P., Marinho, R.R., Vieira, L.A. (2012). Development of an oxyrutile electrode for wet welding. Weld. J., 12, 319328.

8. Klett, J., Mattos, I.B.F., Maier, H.J., e Silva, R.H.G., Hassel, T. (2020). Control of the diffusible hydrogen content in different steel phases through the targeted use of different welding consumables in underwater wet welding. Mater. Corr. 1-13. https://doi.org/10.1002/maco.202011963

9. Klett, J., Hassel, T. (2020). Reducing the risk of hydrogen-induced cold cracks in hyperbaric wet welding of highstrength steels by using austenitic welding consumables. Weld. Cut. 19 (1), 5460 .

10. Rowe, M., Liu, S. (2001). Recent developments in underwater wet welding. Sci. Technol. Weld Joi. 6 (6), 387-396. https://doi.org/10.1179/stw.2001.6.6.387

11. Li, H., Liu, D., Song, Y., Yan, Y., Guo, N., Feng, J. (2017). Microstructure and mechanical properties of underwater wet welded high-carbon-equivalent steel Q460 using austenitic

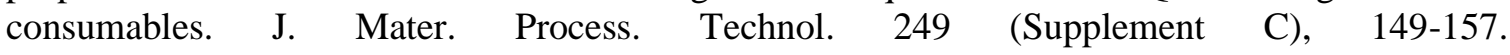
https://doi.org/10.1016/j.jmatprotec.2017.06.009

12. Tomków, J., Fydrych, D., Rogalski, G. (2019). Role of Bead Sequence in Underwater Welding. Materials 12, 3372. https://doi.org/10.3390/ma12203372

13. Tomków, J., Rogalski, G., Fydrych, D., Łabanowski, J. (2019). Advantages of the Application of the Temper Bead Welding Technique During Wet Welding. Materials 12, 915. https://doi.org/10.3390/ma12060915

14. Fydrych, D., Świerczyńska, A., Rogalski, G., Łabanowski, J. (2016). Temper Bead Welding of S420G2+M Steel in Water Environment, Adv. Mater. Sci. 16 (4), 5-16. https://doi.org/10.1515/adms-2016-0018

15. Tomków, J., Fydrych, D., Rogalski, G., Łabanowski, J. (2018). Temper Bead Welding of S460N Steel in Wet Welding Conditions. Adv. Mater. Sci. 18 (3), 48-56. https://doi.org/10.1515/adms2017-0036

16. Reisgen, U., Olschok, S., Lenz, K. (2018). Induktive Wärmenachbehandlung nass unterwassergeschweißter hochfester Feinkornbaustähle. Schweißen Schneiden, 70 (6), 396-403.

17. Brätz, O., Henkel, K.-M., Klett, J., Hassel, T. (2018). Anwendung der Induktion für schweißtechnische Erwärmung beim nassen Lichtbogenhandschweißen unter Wasser. Kolloquium Induktionserwärmung in der schweißtechnischen Fertigung, 2, 29-35.

18. Zhang, H.T., Dai, X.Y., Feng, J.C., Hu, L.L. (2015). Preliminary investigation on real-time induction heating-assisted underwater wet welding. Weld. J. 94 (1), 8-15.

19. Sun, Q.J., Cheng, W.Q., Liu, Y.B., Wang, J.F., Cai, C.W., Feng, J.C. (2016). Microstructure and mechanical properties of ultrasonic assisted underwater wet welding joints. Mater. Des. 103, 6370. https://doi.org/10.1016/j.matdes.2016.04.019

20. Chen, H., Guo, N., Liu, C., Zhang, X., Xu, C., Wang, G. (2020). Insight into hydrostatic pressure effects on diffusible hydrogen content in wet welding joints using in-situ X-ray imaging method. Int. J. Hydrogen Energy 45, 10219-10226. https://doi.org/10.1016/j.ijhydene.2020.01.195 
21. Chen, H., Guo, N., Xu, K., Xu, C., Zhou, L., Wang, G. (2020). In-situ observations of melt degassing and hydrogen removal enhanced by ultrasonics in underwater wet welding. Mater. Des. 188, 108482. https://doi.org/10.1016/j.matdes.2020.108482

22. Li, H., North, T.H. (1992). Hydrogen Absorption and Hydrogen Cracking in High Strength Weld Metal. Key. Eng. Mater. 69-70, 95-112. https://doi.org/10.4028/www.scientific.net/KEM.69-7

23. Kiefer, J.H. (1996). Effects of Moisture Contamination and Welding Parameters on Diffusible Hydrogen. Weld. J. 75 (5), 155-161.

24. Mutnansky, V. (1983). Shielded gas welding of high-strength martensitic steel. Zvaranie 32 (9), 269-273.

25. Kussike, S.M. (2015). Hydrophobierung von Stabelektroden für das "nasse" Lichtbogenhandschweißen unter Wasser. Ph.D. Thesis, Leibniz Universität Hannover, Germany.

26. Deutscher Verband für Schweißtechnik. (2017). DVS Merkblatt 1818: Ausführung von Lichtbogenschweißarbeiten in nasser Umgebung.

27. Tomków, J., Fydrych, D., Rogalski, G., Łabanowski, J. (2019). Effect of the welding environment and storage time of electrodes on the diffusible hydrogen content in deposited metal. Rev. de Metal. 55 (1), e140. https://doi.org/10.3989/revmetalm.140

28. Mielnicka, K., Wolski, A., Świerczyńska, A., Rogalski, G., Fydrych, D. (2019). Determination of moisture resistance of covered electrodes according to PN-EN ISO 14372. Weld. Tech. Rev. vol. 91 (7), 23-30. https://doi.org/10.26628/wtr.v91i7.1049

29. Tomków, J., Fydrych, D., Wilk, K. (2020). Effect of Electrode Waterproof Coating on Quality of Underwater Wet Welded Joints. Mater. 13 (13), 2947. https://doi.org/10.3390/ma13132947

30. Hecht-Linowitzki, V., Klett, J., Hassel, T. (2016). Automated Underwater Arc Welding. Proceedings of the Symposium on Automated Systems and Technologies, 10/16, 21-26.

31. ISO - International Organization for Standardization. (2018). ISO 3690:2018-07: Welding and Allied Processes - Determination of Hydrogen Content in Arc Weld Metal.

32. Klett, J., Wolf, T., Maier, H.J., Hassel, T. (2020). The Applicability of the Standard DIN EN ISO 3690 for the Analysis of Diffusible Hydrogen Content in Underwater Wet Welding. Materials 13 (17), 3750. https://doi.org/10.3390/ma13173750

33. Ando, S., Asahina, T. (1983). A Study on the Metallurgical Properties of Steel Welds with Underwater Gravity Welding. In Underwater Welding, Proceedings of the International Conference. 255-261.

34. Da Silva, W.C.D., Ribeiro, L.F., Bracarense, A.Q., Pessoa, E.C.P. (2012). Effect of the Hydrostatic Pressure in the Diffusible Hydrogen at the Underwater Wet Welding. Proceedings of the ASME 31st International Conference OMAE2012-83002 No. 44939, 1-8.

35. Kong, X., Li, C., Zou, Y., Zhang, J., Hu, Y., Wang, J., Qaddoumi, N., Koh, S.-K., Devlin, J. (2016). Measurement and Analysis of the Diffusible Hydrogen in Underwater Wet Welding Joint. MATEC Web Conf., 39, 03004. https://doi.org/10.1051/matecconf/20163903004

36. Moreno-Uribe, A.M., Bracarense, A.Q., Pessoa, E.C.P. (2020). The Effect of Polarity and Hydrostatic Pressure on Operational Characteristics of Rutile Electrode in Underwater Welding. Materials 13, 5001. https://doi.org/10.3390/ma13215001

37. Parshin, S.G., Levchenko, A.M., Maystro, A.S. (2020). Metallurgical Model of Diffusible Hydrogen and Non-Metallic Slag Inclusions in Underwater Wet Welding of High-Strength Steel. Metals 10, 1498. https://doi.org/10.3390/met10111498 